\title{
Selenoprotein R Protects Human Lens Epithelial Cells against D-Galactose-Induced Apoptosis by Regulating Oxidative Stress and Endoplasmic Reticulum Stress
}

\author{
Jie Dai, Hongmei Liu, Jun Zhou and Kaixun Huang * \\ Hubei Key Laboratory of Bioinorganic Chemistry \& Materia Medica, \\ School of Chemistry and Chemical Engineering, Huazhong University of Science and Technology, \\ 1037 Luoyu Road, Hongshan, Wuhan 430074, China; daijiehust@163.com (J.D.); \\ hongmeiliuhust@hust.edu.cn (H.L.); hustzhj@hust.edu.cn (J.Z.) \\ * Correspondence: hxxzrf@mail.hust.edu.cn; Tel./Fax: +86-27-8754-3632
}

Academic Editor: Eva Freisinger

Received: 31 December 2015; Accepted: 4 February 2016; Published: 10 February 2016

\begin{abstract}
Selenium is an essential micronutrient for humans. Much of selenium's beneficial influence on health is attributed to its presence within 25 selenoproteins. Selenoprotein R (SelR), known as methionine sulfoxide reductase B1 (MsrB1), is a selenium-dependent enzyme that, like other Msrs, is required for lens cell viability. In order to investigate the roles of SelR in protecting human lens epithelial (hLE) cells against damage, the influences of SelR gene knockdown on D-galactose-induced apoptosis in hLE cells were studied. The results showed that both D-galactose and SelR gene knockdown by siRNA independently induced oxidative stress. When SelR-gene-silenced hLE cells were exposed to D-galactose, glucose-regulated protein 78 (GRP78) protein level was further increased, mitochondrial membrane potential was significantly decreased and accompanied by a release of mitochondrial cytochrome $\mathrm{c}$. At the same time, the apoptosis cells percentage and the caspase-3 activity were visibly elevated in hLE cells. These results suggested that SelR might protect hLE cell mitochondria and mitigating apoptosis in hLE cells against oxidative stress and endoplasmic reticulum (ER) stress induced by D-galactose, implying that selenium as a micronutrient may play important roles in hLE cells.
\end{abstract}

Keywords: selenoprotein R; D-galactose; lens epithelial cells; apoptosis; oxidative stress; endoplasmic reticulum stress; mitochondrial membrane potential

\section{Introduction}

Selenium is an essential micronutrient for humans. Much of selenium's beneficial influence on health is attributed to its presence within 25 selenoproteins [1-5]. Previous studies showed that supplementation of selenium could slow the development of naphthalene cataract, possibly by attenuating the oxidative stress in the lens [6]. However, the mechanism of selenium in preventing or slowing cataract onset and progression remains virtually unclear.

Oxidative stress is believed to play a major role in cataract formation. The research results $[7,8]$ showed that the content of methionine sulfoxide (MetO) in membrane-bound protein of the lens increases with age, and in cataracts as much as $60 \%$ of the total membrane-bound protein methionine is found as MetO, suggesting a possible linkage between methionine oxidation and age-related cataracts. However, MetO can be reduced to Met by a class of enzymes known as methionine sulfoxide reductases (Msrs) [8,9]. Among Msrs, MsrB1 is the only selenoprotein, named as Selenoprotein R (SelR). SelR is widely distributed throughout different tissues [10] and localized in the cell nucleus and cytosol [11,12]. 
Because of the linkage between MetO and cataracts, SelR has received significant attention recently. Marchetti MA et al. proved that SelR, like other Msrs, is required for lens cell viability [13]. Our previous studies showed that SelR might play important roles in regulating redox homeostasis and attenuating ER stress induced by oxidative stress in human lens epithelial (hLE) cells [14-16].

D-Galactose (D-gal) is classified as a reducing monosaccharide. It is abundantly present in milk products and other non-dairy foodstuffs such as fruits and vegetables [17]. At normal concentrations it is metabolized into glucose, but at higher doses is converted into aldose and hydroperoxide through the action of D-galactose oxidase resulting in the formation of reactive oxygen species (ROS) [18]. D-Galactose-induced rat model of cataract has widely been investigated [19-21]. Three mechanisms involved in D-galactose-induced cataract have been proposed [21]. Oxidative stress is believed to play a pivotal role in cataract formation [22-24]. Several reports showed that oxidative damage contributed to D-galactose cataract development in immature and mature rats [25-28]. The lipid peroxide content was increased and gluthatione (GSH) content was decreased in lenses of male Wistar rats fed a D-galactose diet [28]. When the hLE cells were incubated with $125 \mathrm{mM}$ D-galactose, the viability decreased and apoptosis increased and was accompanied by an increase of reactive oxygen species (ROS) level and decrease of GSH level [29]. However, the role of SelR protecting human lens epithelial cells against D-galactose-induced apoptosis has not been reported.

It is well known that damage to hLE cells is an early event in cataract development [22,23]. Cell apoptosis is suggested to be a crucial cause of cataract formation. It was reported that the incidence of apoptosis is greater in the LE cells of diabetic cataract rats and humans than that in those of non-diabetics [30]. Mulhern et al. [31] proved that in D-galactosemic rat lenses, mitotic LE cells in the central and peripheral mitotic zone died first, followed by the central, nonmitotic LE cells, and eventually the remaining LE cells.

In order to explore the nutritional role of selenium in a lens, in the present studies, we chose SelR as an example of 25 selenoproteins, used SRA01/04 cells, one kind of human lens epithelial cell line [32], as an experimental model and investigated the effect of SelR gene knockdown by RNAi on apoptosis in hLE cells. Oxidative stress, ER stress and mitochondrial dysfunctions associated with cell apoptosis were assayed. Our results suggest that SelR might protects hLE cells against D-galactose-induced apoptosis by inhibiting oxidative damage and ER stress via a mitochondrial apoptotic pathway, suggesting selenium as a micronutrient may play important roles in hLE cells.

\section{Result}

\subsection{SelR Gene Silence Effectiveness}

In order to evaluate the efficiency of SelR gene knockdown in hLE cells, levels of SelR mRNA and protein were determined before and after SelR siRNA transfection. The random siRNA as negative control did not affect the mRNA and protein expression levels of SelR. As shown in Figure 1, SelR mRNA (Figure 1a) and protein levels (Figure 1b) in SelR gene-silenced hLE cells were suppressed approximately $64.8 \%(p<0.001)$ and $71.7 \%(p<0.001)$, respectively, compared with normal control, showing that the expression of SelR was successfully depressed by siRNA. Influence of $\mathrm{Na}_{2} \mathrm{SeO}_{3}$ on the expression of SelR in hLE cells was also analyzed. SelR mRNA (Figure 1a) and protein (Figure 1b) expression in cells treated with $\mathrm{Na}_{2} \mathrm{SeO}_{3}(1 \mu \mathrm{M})$ were increased $58.8 \%$ and $34.0 \%$, respectively, compared with the negative control. When hLE cells were treated with SelR siRNA, SelR mRNA and protein expression in cells exposed with $\mathrm{Na}_{2} \mathrm{SeO}_{3}(1 \mu \mathrm{M})$ were increased $15.1 \%$ and $8.8 \%$, respectively, compared with the SelR siRNA group. 

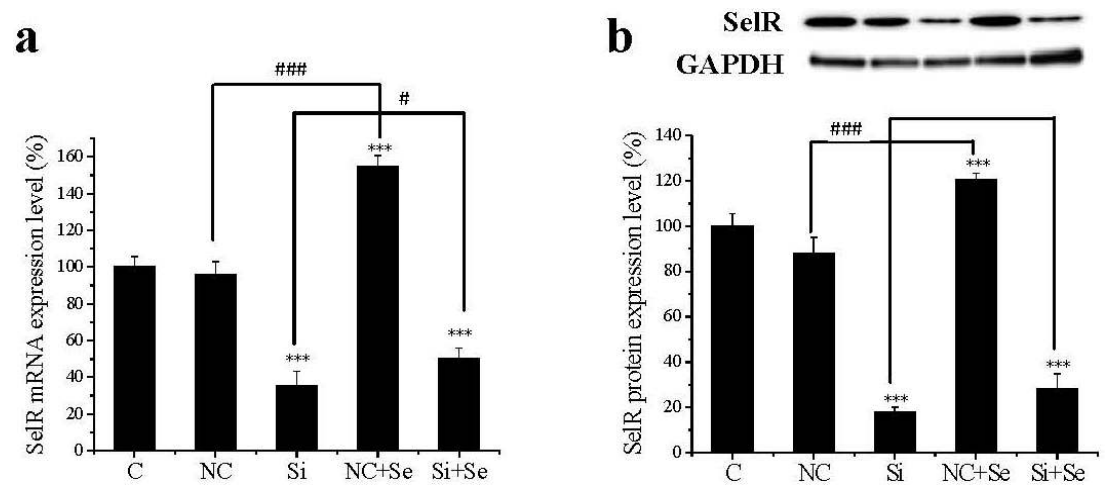

Figure 1. The efficiency of Selenoprotein R (SelR) gene knockdown in human lens epithelial (hLE) cells. SelR mRNA (a) and protein levels (b) in hLE cells were assayed by Real-time PCR and western blot using GAPDH as a reference. Data are the mean \pm SD of at least three independent experiments. *** $p<0.001$, compared to control group; ${ }^{*} p<0.05,{ }^{\# \#} p<0.001$. C: control cells; NC: negative control celle; Si: SelR siRNA cells; $\mathrm{NC}+\mathrm{Se}$ : negative control cells exposed to $\mathrm{Na}_{2} \mathrm{SeO}_{3}(1 \mu \mathrm{M})$ for $36 \mathrm{~h}$; $\mathrm{Si}+\mathrm{Se}$ : SelR siRNA cells exposed to $\mathrm{Na}_{2} \mathrm{SeO}_{3}(1 \mu \mathrm{M})$ for $36 \mathrm{~h}$.

\subsection{Effect of SelR Gene Knockdown and $\mathrm{Na}_{2} \mathrm{SeO}_{3}$ on Cell Viability in D-Galactose-Treated hLE Cells}

The effect of SelR gene knockdown by RNAi on D-galactose-induced hLE cells death was investigated using the MTT assay. As shown in Figure 2a, the viability of cells was significantly decreased in a concentration-dependent manner. After the incubation with 50, 100, 150, 200 and $250 \mathrm{mM}$ D-galactose for $36 \mathrm{~h}$, cell viabilities were $96.36 \%, 90.01 \%, 76.56 \%(p<0.001), 50.74 \%(p<0.001)$ and $37.13 \%(p<0.001)$ of untreated cells, respectively. Effect of SelR gene knockdown and $\mathrm{Na}_{2} \mathrm{SeO}_{3}$ on D-galactose-induced cell viabilities was shown in Figure 2b. The viabilities of SelR-gene-silenced cells (Si group), cells treated with $150 \mathrm{mM}$ D-galactose for $36 \mathrm{~h}$ (G group) and SelR-gene-silenced cells followed with D-galactose treatment (Si+G group) were approximately $93.10 \%, 73.40 \%(p<0.001)$ and $60.63 \%(p<0.001)$ of negative control, respectively. When hLE cells treated with D-galactose $(150 \mathrm{mM})$ were cultivated with $\mathrm{Na}_{2} \mathrm{SeO}_{3}(1 \mu \mathrm{M})$ for $36 \mathrm{~h}$, the viabilities of $\mathrm{G}+\mathrm{Se}$ group and $\mathrm{Si}+\mathrm{G}+\mathrm{Se}$ group were increased by $8.5 \%$ and $10.7 \%$, respectively, compared to $\mathrm{G}$ group and $\mathrm{Si}+\mathrm{G}$ group.
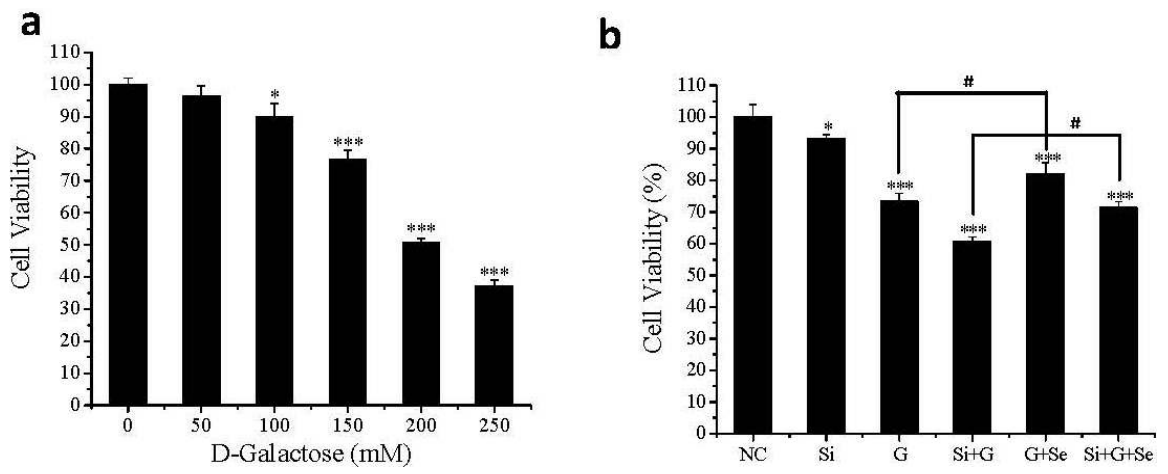

Figure 2. Effect of $\mathrm{SelR}$ gene knockdown and $\mathrm{Na}_{2} \mathrm{SeO}_{3}$ on D-galactose-induced cell death. (a) The viability of hLE cells after treatment with the indicated concentrations of D-galactose; (b) The viability of hLE cells in the indicated groups. Data are the mean \pm SD of at least three independent experiments. ${ }^{*} p<0.05,{ }^{* * *} p<0.001$, compared to the negative control group; $\#<0.05$. NC: negative control cells; Si: cells with SelR siRNA transfection for $24 \mathrm{~h}$; G: cells exposed to D-galactose (150 mM) for $36 \mathrm{~h}$; Si+G: cells with SelR siRNA transfection followed by D-galactose exposure; G+Se: cells exposed to galactose $(150 \mathrm{mM})$ and $\mathrm{Na}_{2} \mathrm{SeO}_{3}(1 \mu \mathrm{M})$ for $36 \mathrm{~h}$; $\mathrm{Si}+\mathrm{G}+\mathrm{Se}$ : cells with SelR siRNA transfection followed by galactose and $\mathrm{Na}_{2} \mathrm{SeO}_{3}$ exposure. 


\subsection{Effect of SelR Gene Knockdown and $\mathrm{Na}_{2} \mathrm{SeO}_{3}$ on D-Galactose-Induced Cell Apoptosis}

Morphological changes of cell nuclei were observed using a fluorescence microscope by staining with Hoechst 33258 (Figure 3a). As shown in Figure 3a, the negative control hLE cells nucleus remained uniformly stained (Figure 3a (NC)). After treatment with $150 \mathrm{mM}$ D-galactose, a typical apoptotic morphology was visible in some cells (Figure 3a $(G)$ ). When SelR-gene-silenced cells were treated with $150 \mathrm{mM}$ D-galactose, the cells exhibited obvious nuclear condensation and fragmentation (Figure 3a $(\mathrm{Si}+\mathrm{G}))$. When hLE cells treated with D-galactose $(150 \mathrm{mM})$ were cultivated with $\mathrm{Na}_{2} \mathrm{SeO}_{3}(1 \mu \mathrm{M})$ for $36 \mathrm{~h}$, a decreased number of cells exhibiting fragmented nuclei were observed in $\mathrm{G}+\mathrm{Se}$ group and $\mathrm{Si}+\mathrm{G}+\mathrm{Se}$ group, compared to $\mathrm{G}$ group and $\mathrm{Si}+\mathrm{G}$ group.

Quantitative analysis of cell apoptosis was carried out using flow cytometry. As shown in Figure 3, the early apoptotic and late apoptotic fraction, respectively, was $1.84 \%$ and $0.32 \%$ in negative control cells (Figure $3 \mathrm{~b}(\mathrm{NC})$ ); $2.65 \%$ and $4.33 \%$ in cells transfected with SelR siRNA (Figure 3b (Si)); $12.97 \%$ and $10.65 \%$ in cells exposed to D-galactose (Figure $3 \mathrm{~b}(\mathrm{G})$ ); $20.61 \%$ and $18.11 \%$ in cells transfected with SelR siRNA followed by D-galactose stimulation (Figure $3 b(\mathrm{Si}+\mathrm{G})$ ). When hLE cells were treated with SelR siRNA followed by D-galactose and $\mathrm{Na}_{2} \mathrm{SeO}_{3}$ treatment, the early and late apoptotic fraction was $7.06 \%$ and $10.16 \%$ (Figure $3 \mathrm{~b}$ ( $\mathrm{Si}+\mathrm{G}+\mathrm{Se}$ )). Compared to $\mathrm{G}$ group and $\mathrm{Si}+\mathrm{G}$ group, the total apoptosis cell percentage was decreased to 0.57 -fold and 0.45 -fold in $\mathrm{G}+\mathrm{Se}$ group and $\mathrm{Si}+\mathrm{G}+\mathrm{Se}$ group, respectively (Figure 3c). Seleniun supplementation may obviously decrease the percentage of apoptosis induced by D-galactose or SelR siRNA and D-galactose in hLE cells.

a
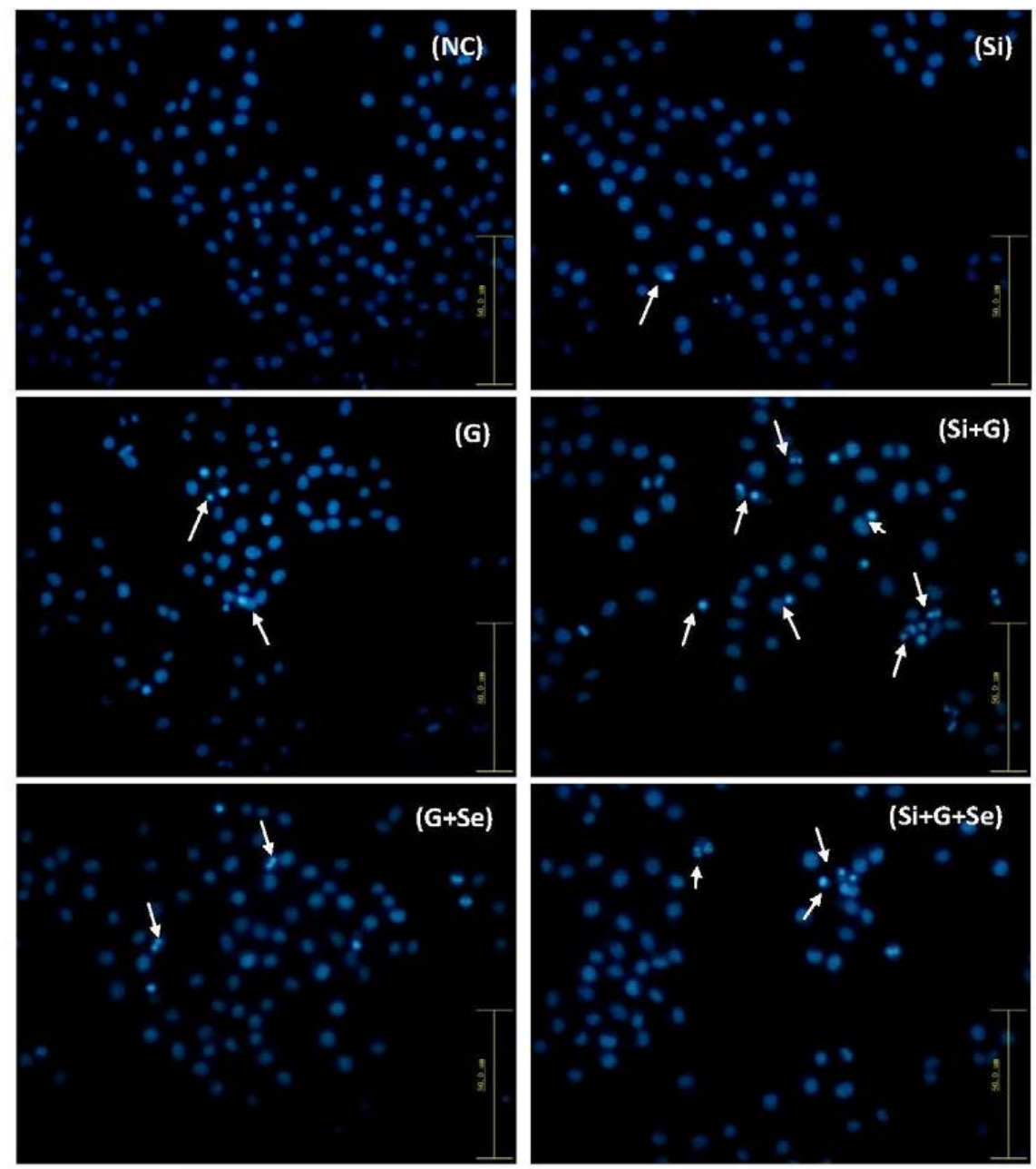

Figure 3. Cont. 

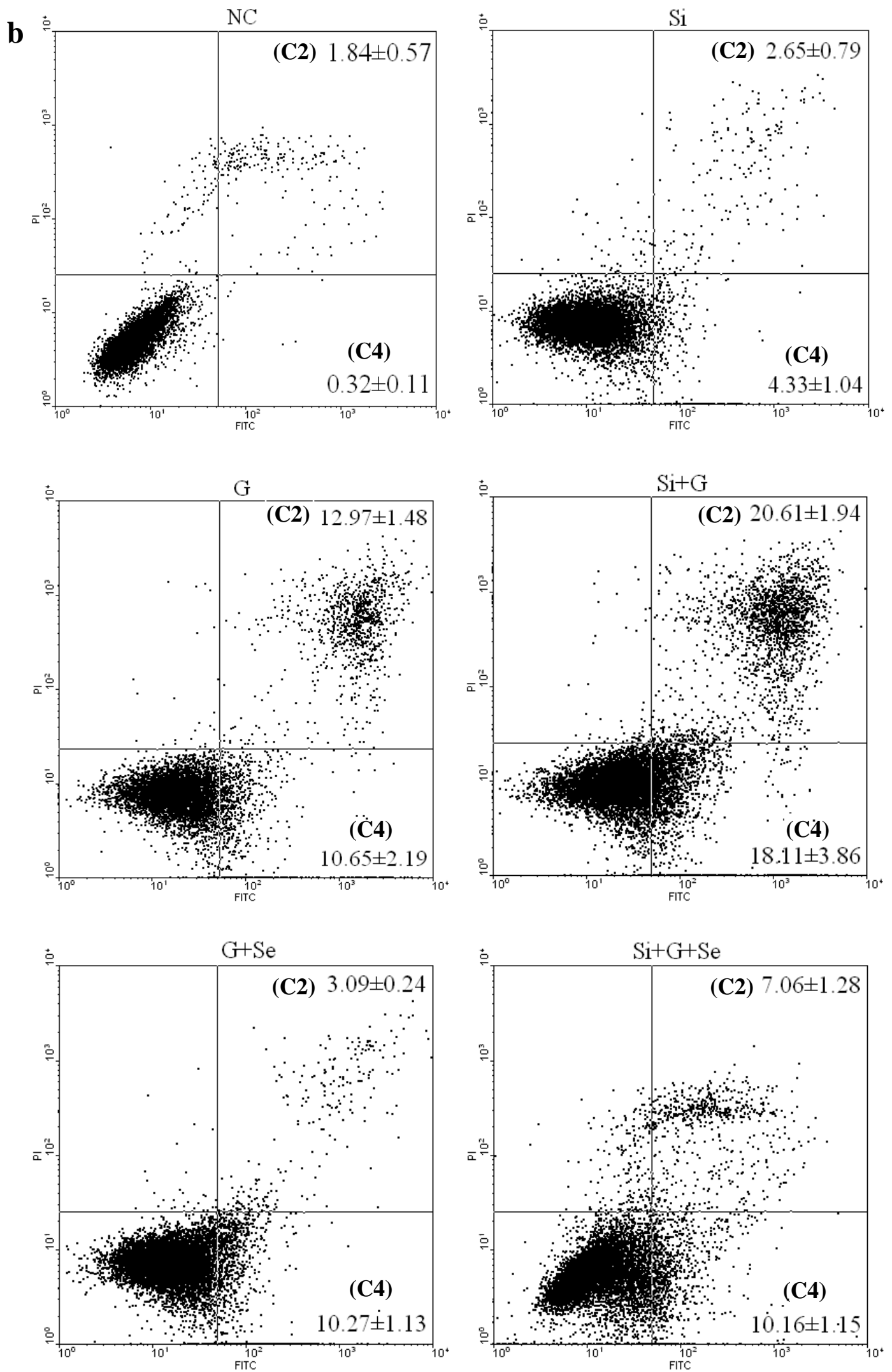

Figure 3. Cont. 
c

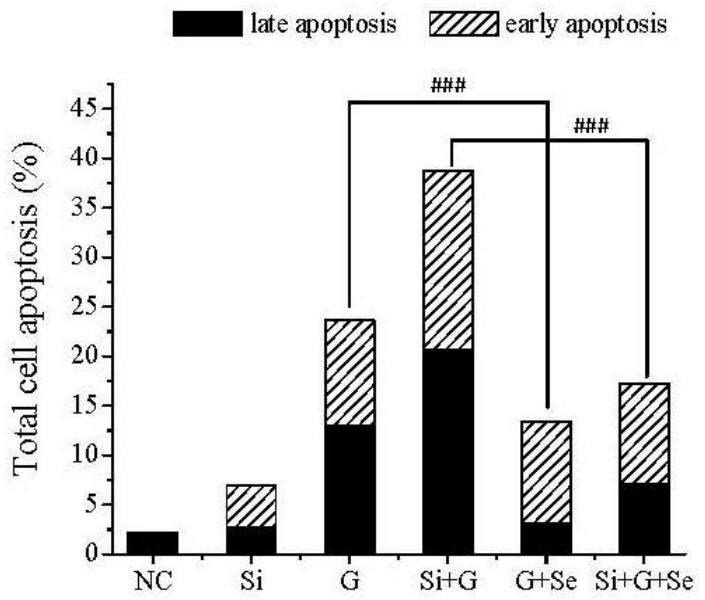

Figure 3. Effect of SelR gene knockdown and $\mathrm{Na}_{2} \mathrm{SeO}_{3}$ on D-galactose-induced cell apoptosis. (a) hLE cell morphological changes in the indicated groups under the fluorescence microscopy after staining with Hoechst $33258(200 \times)$; (b) Quantitative analysis of hLE cells apoptosis using flow cytometry by an Annexin-V-FITC apoptosis detection kit; (c) Total apoptosis cell percentage in the indicated groups. The black body and oblique line represent number of the late apoptosis cells (C2) and early apoptosis cells (C4). Data are the mean \pm SD of at least three independent experiments. Arrows, examples of apoptotic cells. ${ }^{\# \#} p<0.001$. NC: negative control cells; Si: cells with SelR siRNA transfection for 24 h; G: cells exposed to D-galactose $(150 \mathrm{mM})$ for $36 \mathrm{~h}$; $\mathrm{Si}+\mathrm{G}$ : cells with SelR siRNA transfection followed by D-galactose exposure; G+Se: cells exposed to D-galactose (150 mM) and $\mathrm{Na}_{2} \mathrm{SeO}_{3}(1 \mu \mathrm{M})$ for $36 \mathrm{~h}$; $\mathrm{Si}+\mathrm{G}+\mathrm{Se}$ : cells with $\mathrm{SelR}$ siRNA transfection followed by D-galactose and $\mathrm{Na}_{2} \mathrm{SeO}_{3}$ exposure.

\subsection{Effect of SelR Gene Knockdown and $\mathrm{Na}_{2} \mathrm{SeO}_{3}$ on GPx Activity in D-Galactose-Treated hLE Cells}

As shown in Figure 4, compared to negative control cells (NC), GPx activity was decreased to 92.9\%, 46.5\% and 41.6\%, respectively, in SelR-gene-silenced cells (Si), D-galactose-exposed cells (G) and cells transfected with SelR siRNA followed by D-galactose-exposure ( $\mathrm{Si}+\mathrm{G})$. When hLE cells treated with D-galactose $(150 \mathrm{mM})$ were cultivated with $\mathrm{Na}_{2} \mathrm{SeO}_{3}(1 \mu \mathrm{M})$ for $36 \mathrm{~h}, \mathrm{GPx}$ activity was increased to approximately 1.75- and 1.74-fold in G+Se group and $\mathrm{Si}+\mathrm{G}+\mathrm{Se}$ group, compared to G group and $\mathrm{Si}+\mathrm{G}$ group.

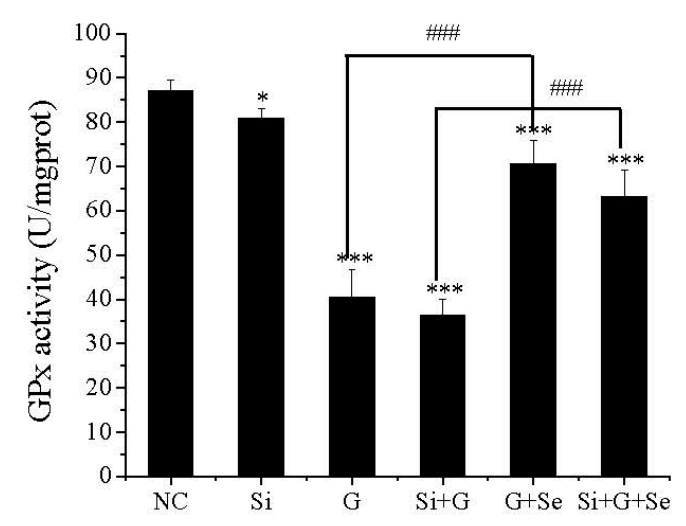

Figure 4. Alterations of intracellular glutathione peroxidase 1 (GPx) activity. Data are the mean \pm SD of at least three independent experiments. ${ }^{*} p<0.05,{ }^{* * *} p<0.001$, compared to the negative control group; \#\#\# $p<0.001$. NC: negative control cells; Si: cells with SelR siRNA transfection for $24 \mathrm{~h}$; G: cells exposed to D-galactose (150 mM) for $36 \mathrm{~h}$; Si+G: cells with SelR siRNA transfection followed by D-galactose exposure; G+Se: cells exposed to D-galactose $(150 \mathrm{mM})$ and $\mathrm{Na}_{2} \mathrm{SeO}_{3}(1 \mu \mathrm{M})$ for $36 \mathrm{~h}$; $\mathrm{Si}+\mathrm{G}+\mathrm{Se}$ : cells with SelR siRNA transfection followed by D-galactose and $\mathrm{Na}_{2} \mathrm{SeO}_{3}$ exposure. 


\subsection{Effect of SelR Gene Knockdown and $\mathrm{Na}_{2} \mathrm{SeO}_{3}$ on D-Galactose-Induced ROS, MDA, PC and TSH Levels}

ROS generation was measured using fluorescence microscopy (Figure 5a). The fluorescent intensity of ROS was enhanced in the cells treated with SelR SiRNA (Figure 5a (Si)) and in the cells exposed to D-galactose (Figure 5a (G)), compared to negative control cells (Figure 5a (NC)). The intensity was further enhanced in SelR-gene-silenced cells exposed to D-galactose (Figure 5a $(\mathrm{Si}+\mathrm{G}))$. Meanwhile, intracellular ROS levels were quantified by flow cytometry using DCFH-DA fluorescent probes. As shown in Figure 5b, compared to negative control cells (NC), intracellular ROS level was increased to 1.43-fold, 2.57-fold and 3.33-fold, respectively, in SelR-gene-silenced cells (Si), D-galactose-exposed cells (G) and cells transfected with SelR siRNA followed by D-galactose-exposure $(\mathrm{Si}+\mathrm{G})$. When hLE cells treated with D-galactose $(150 \mathrm{mM})$ were cultivated with $\mathrm{Na}_{2} \mathrm{SeO}_{3}(1 \mu \mathrm{M})$ for $36 \mathrm{~h}$, ROS level was decreased to approximately 0.69 - and 0.86-fold in $\mathrm{G}+\mathrm{Se}$ group and $\mathrm{Si}+\mathrm{G}+\mathrm{Se}$ group, compared to $\mathrm{G}$ group and $\mathrm{Si}+\mathrm{G}$ group.

Influence of SelR gene knockdown and $\mathrm{Na}_{2} \mathrm{SeO}_{3}$ on MDA content in hLE cells was also analyzed. As shown in Figure 5c, MDA level in SelR gene knockdown group was 1.84-fold (0.57 nmol/mgprot) of that in control group, after treatment with $150 \mathrm{mM}$ D-galactose, MDA content was increased to approximately 3.71.-fold (1.15 nmol/mgprot) and 5.77-fold (1.79 nmol/mgprot) before and after SelR gene knockdown, respectively, compared with untreated control cells. When hLE cells were treated with D-galactose $(150 \mathrm{mM})$ and $\mathrm{Na}_{2} \mathrm{SeO}_{3}(1 \mu \mathrm{M})$ for $36 \mathrm{~h}$, MDA level was decreased to approximately 0.71 -fold ( $0.82 \mathrm{nmol} / \mathrm{mgprot})$ and 0.68 -fold $(1.21 \mathrm{nmol} / \mathrm{mgprot})$ in $\mathrm{G}+\mathrm{Se}$ group and $\mathrm{Si}+\mathrm{G}+\mathrm{Se}$ group, compared to $\mathrm{G}$ group or $\mathrm{Si}+\mathrm{G}$ group.
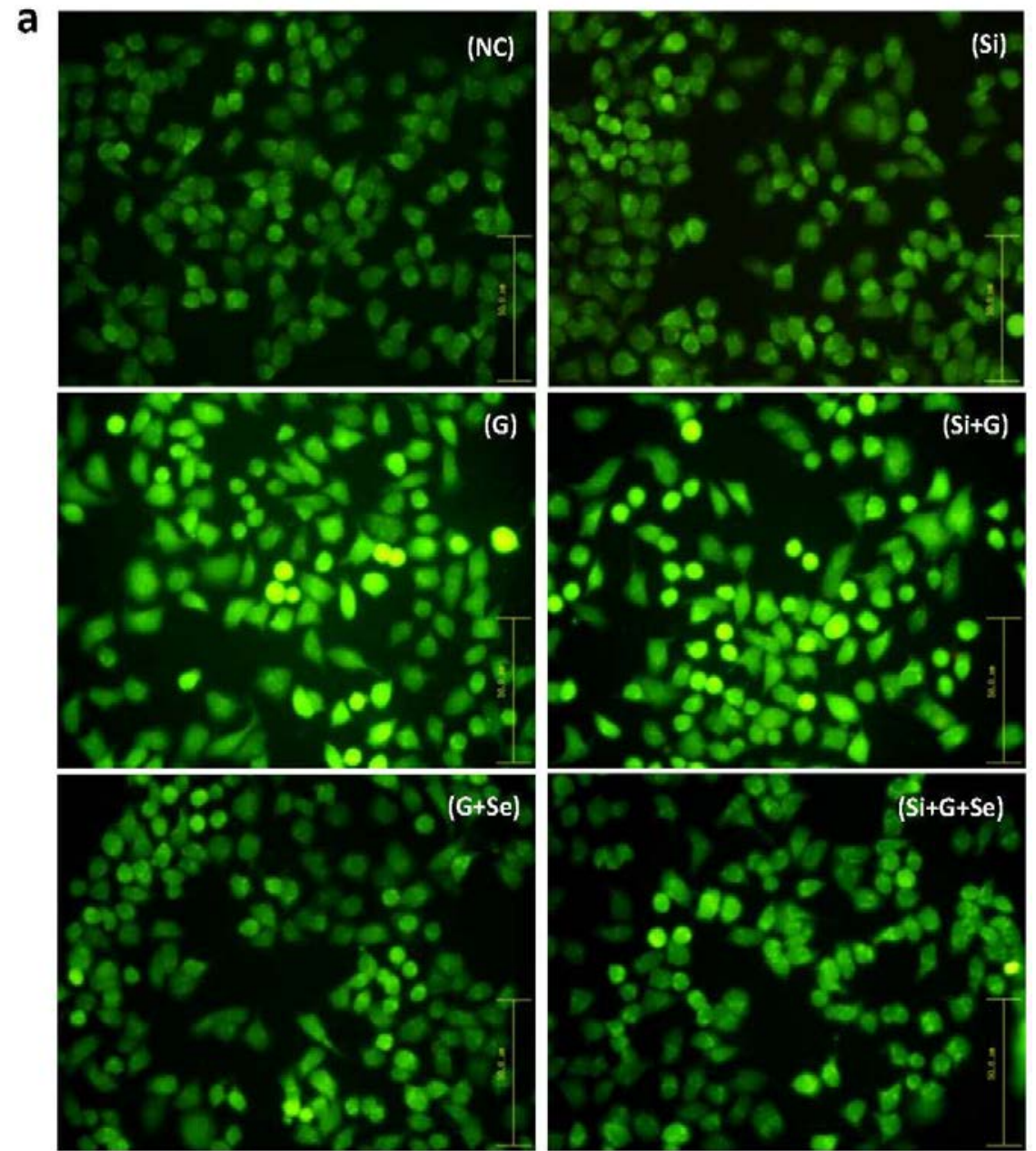

Figure 5. Cont. 

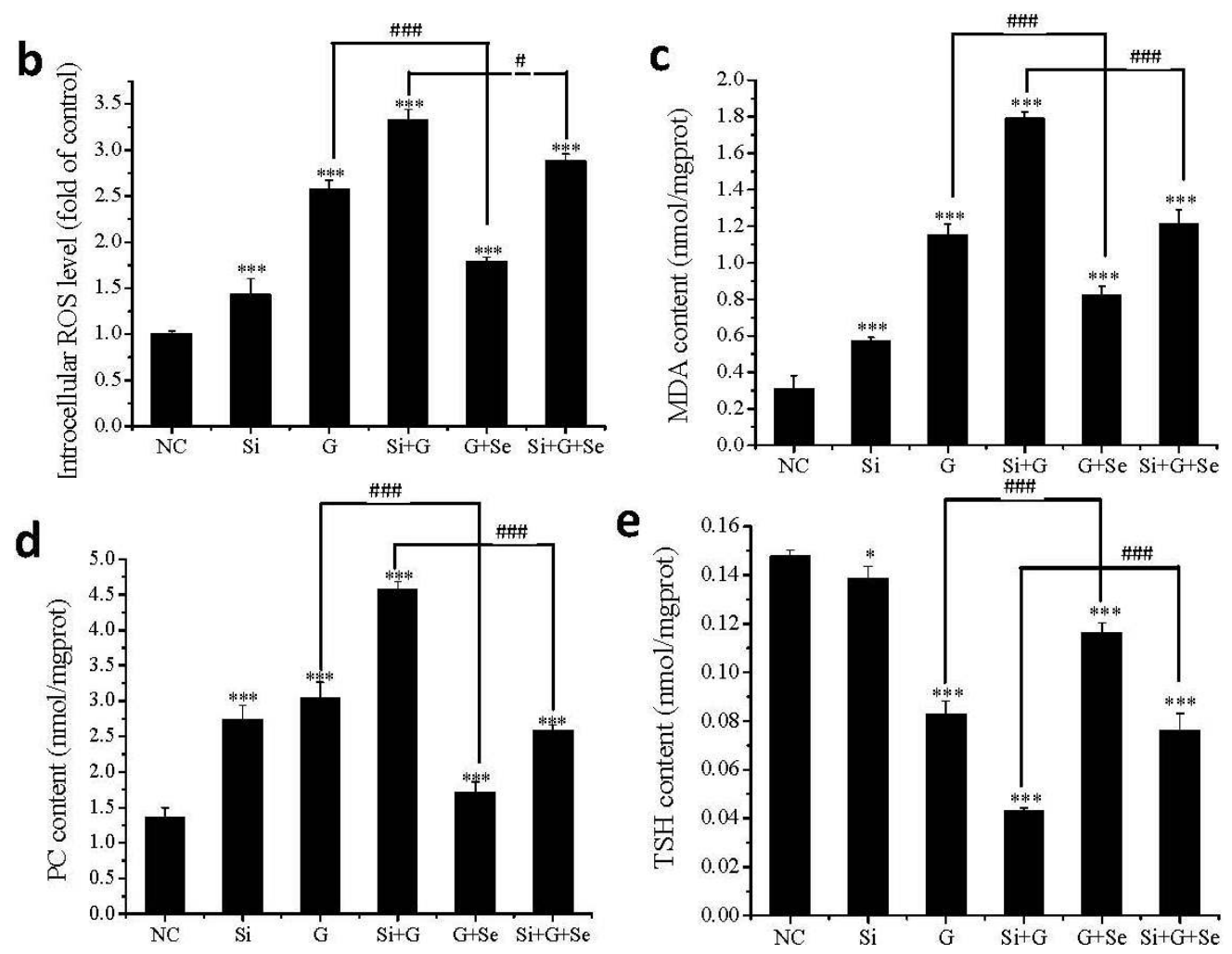

Figure 5. Alterations of intracellular reactive oxygen species (ROS), malondialdehyde (MDA), protein carbonyl (PC) and total mercapto group (TSH) levels. (a) Alterations of fluorescent intensity with ROS levels in the indicated group assayed by $\mathrm{H}_{2}$-DCFDA staining using fluorescent microscopy $(200 \times)$; (b) Intracellular ROS levels in hLE cells in the indicated group; (c) Intracellular MDA levels in hLE cells in the indicated group; (d) Intracellular PC levels in hLE cells in the indicated group; (e) Intracellular TSH levels in hLE cells in the indicated group. Data are the mean \pm SD of at least three independent experiments. ${ }^{*} p<0.05,{ }^{* * *} p<0.001$, compared to the negative control group; ${ }^{\#} p<0.05,{ }^{\# \# \#} p<0.001$. NC: negative control cells; Si: cells with SelR siRNA transfection for $24 \mathrm{~h}$; G: cells exposed to D-galactose (150 mM) for $36 \mathrm{~h}$; Si+G: cells with SelR siRNA transfection followed by D-galactose exposure; G+Se: cells exposed to D-galactose $(150 \mathrm{mM})$ and $\mathrm{Na}_{2} \mathrm{SeO}_{3}(1 \mu \mathrm{M})$ for $36 \mathrm{~h}$; $\mathrm{Si}+\mathrm{G}+\mathrm{Se}$ : cells with SelR siRNA transfection followed by D-galactose and $\mathrm{Na}_{2} \mathrm{SeO}_{3}$ exposure.

Furthermore, the changes of PC content in these groups were almost the same as changes of ROS and MDA generation. As shown in Figure 5d, PC level in SelR gene knockdown group was 2.01-fold $(2.73 \mathrm{nmol} / \mathrm{mgprot})$ of that in negative control group; after treatment with $150 \mathrm{mM}$ D-galactose, PC content was increased to approximately 2.23 -fold ( $3.04 \mathrm{nmol} / \mathrm{mgprot})$ and 3.36 -fold $(4.57 \mathrm{nmol} / \mathrm{mgprot})$ before and after SelR gene knockdown, respectively, compared with negative control cells. When hLE cells were treated with D-galactose $(150 \mathrm{mM})$ and $\mathrm{Na}_{2} \mathrm{SeO}_{3}(1 \mu \mathrm{M})$ for $36 \mathrm{~h}$, PC level was decreased to approximately 0.56 -fold (1.71 nmol/mgprot) and 0.56-fold ( $2.58 \mathrm{nmol} / \mathrm{mgprot})$ in G+Se group and $\mathrm{Si}+\mathrm{G}+\mathrm{Se}$ group, compared to $\mathrm{G}$ group or $\mathrm{Si}+\mathrm{G}$ group.

Sulfhydryl groups represent the level of antioxidants in tissue and are preferentially consumed by free radicals [33]. As shown in Figure 5e, TSH level in SelR gene knockdown group was 93.9\% $(0.139 \mathrm{nmol} / \mathrm{mgprot})$ of that in negative control group; after treatment with $150 \mathrm{mM}$ D-galactose, PC content was decreased to approximately $56.1 \%(0.083 \mathrm{nmol} / \mathrm{mgprot})$ and $29.1 \%(0.043 \mathrm{nmol} / \mathrm{mgprot})$ before and after SelR gene knockdown, respectively, compared with negative control cells. When hLE cells were treated with D-galactose $(150 \mathrm{mM})$ and $\mathrm{Na}_{2} \mathrm{SeO}_{3}(1 \mu \mathrm{M})$ for $36 \mathrm{~h}$, TSH level was increased to approximately 1.39 -fold $(0.116 \mathrm{nmol} / \mathrm{mgprot})$ and 1.77 -fold $(0.076 \mathrm{nmol} / \mathrm{mgprot})$ in G+Se group and $\mathrm{Si}+\mathrm{G}+\mathrm{Se}$ group, compared to $\mathrm{G}$ group and $\mathrm{Si}+\mathrm{G}$ group. 


\subsection{Effect of SelR Gene Knockdown on D-Galactose-Induced Mitochondrial Dysfunctions in hLE Cells}

To investigate the effects of SelR gene knockdown or/and D-galactose treatment on mitochondrial function, mitochondrial transmembrane potential $\Delta \psi \mathrm{m}$ was measured. As shown in Figure 6, the $\Delta \psi \mathrm{m}$ value in SelR-gene-silenced hLE cells was $88 \%$ of that in negative control cells. When the cells were treated with $150 \mathrm{mM}$ D-galactose, the $\Delta \psi \mathrm{m}$ was decreased to approximately $63 \%(p<0.001)$ of normal cell; when SelR-gene-silenced hLE cells were exposed $150 \mathrm{mM}$ D-galactose, the $\Delta \psi \mathrm{m}$ was decreased to approximately $45 \%(p<0.001)$ of the negative control cell.

$\mathbf{a}$
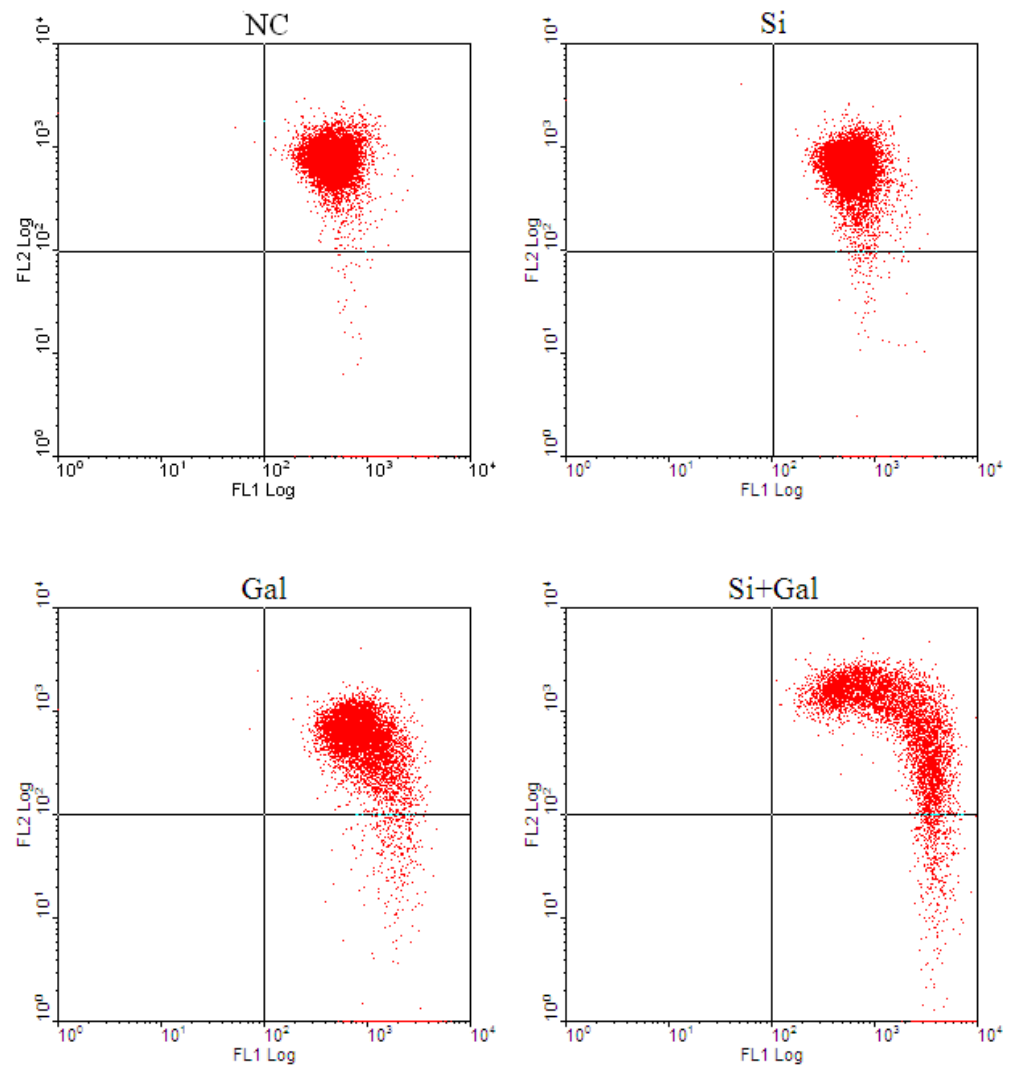

b

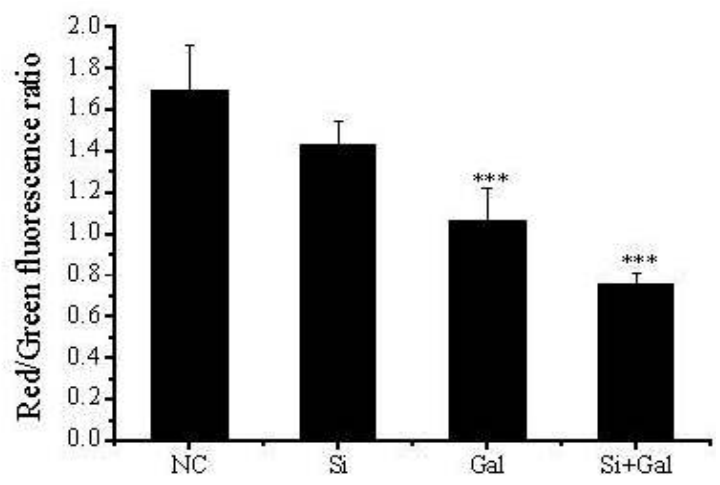

Figure 6. Quantitative analysis of $\Delta \psi \mathrm{m}$ using flow cytometry in hLE cells. (a) Changes of mitochondrial membrane potential $(\Delta \psi \mathrm{m})$ in hLE cells; (b) $\Delta \psi \mathrm{m}$ was quantified using the ratio of red to green fluorescence. Data are the mean \pm SD of at least three independent experiments. ${ }^{* * *} p<0.001$, compared to the negative control group. NC: negative control cells; Si: cells with SelR siRNA transfection for 24 h; Gal: cells exposed to D-galactose $(150 \mathrm{mM})$ for $36 \mathrm{~h}$; Si+Gal: cells with SelR siRNA transfection followed by D-galactose exposure. 


\subsection{Effect of SelR Gene Knockdown on Cytochrome c Release in D-Galactose-Treated hLE Cells}

The negative effects of SelR gene knockdown or D-galactose on mitochondrial function were demonstrated. As shown in Figure 7a, Mitochondrial and cytosolic fractions were separated using a mitochondria/cytosol fractionation kit. The treatments increasd the ratio of cytosolic-to-mitochondrial cytochrome c concentrations, with values of $0.29(\mathrm{NC}), 0.34(\mathrm{Si}), 0.37(\mathrm{G}), 0.64(\mathrm{Si}+\mathrm{G})$, respectively (Figure $7 b$ ).

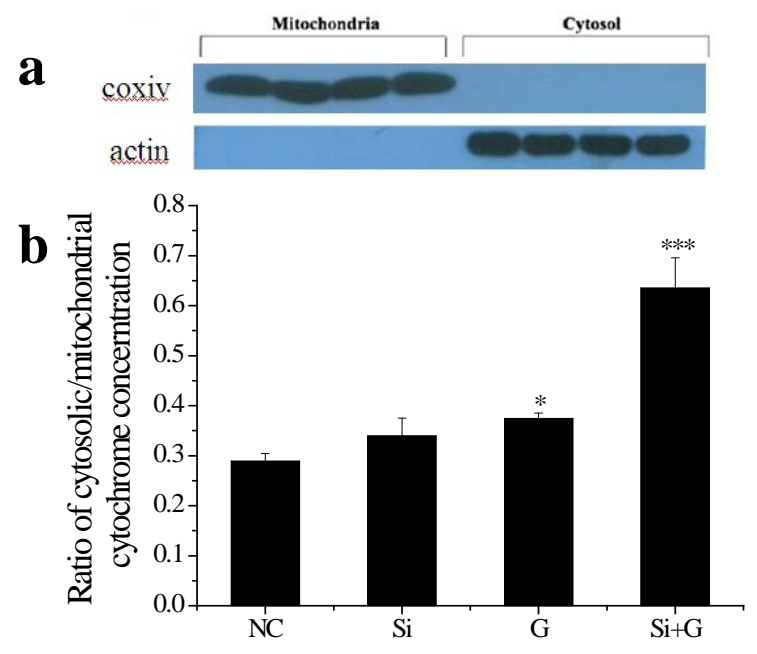

Figure 7. Effect of SelR gene knockdown on D-galactose-induced cytochrome c release. (a) Purity of cytosolic and mitochondrial fractions; (b) ELISA quantization of cytochrome c protein in cytosolic and mitochondrial fractions. The data are expressed as the ratio of cytosolic-to- mitochondrial cytochrome c concentrations. ${ }^{*} p<0.05,{ }^{* * *} p<0.001$, compared to the negative control group. NC: negative control cells; Si: cells with SelR siRNA transfection for $24 \mathrm{~h}$; G: cells exposed to D-galactose (150 mM) for $36 \mathrm{~h}$; $\mathrm{Si}+\mathrm{G}$ : cells with SelR siRNA transfection followed by D-galactose exposure.

\subsection{Effect of SelR Gene Knockdown on Caspase-3 Activity in D-Galactose-Treated hLE Cells}

To understand the pathway of D-galactose -induced hLE cells apoptosis, we analyzed caspase-3 activity. As shown in Figure 8, caspase-3 activities were increased after SelR gene knockdown or gactose exposure, with values of 2.51 -fold $(p<0.001)$ and 2.69 -fold $(p<0.001)$ of untreated cells group, respectively. In SelR-gene-silenced cells followed by $150 \mathrm{mM}$ D-galactose treatment, the caspase-3 activity was 4.73 -fold $(p<0.001)$ higher compared to negative control hLE cells (Figure 8).

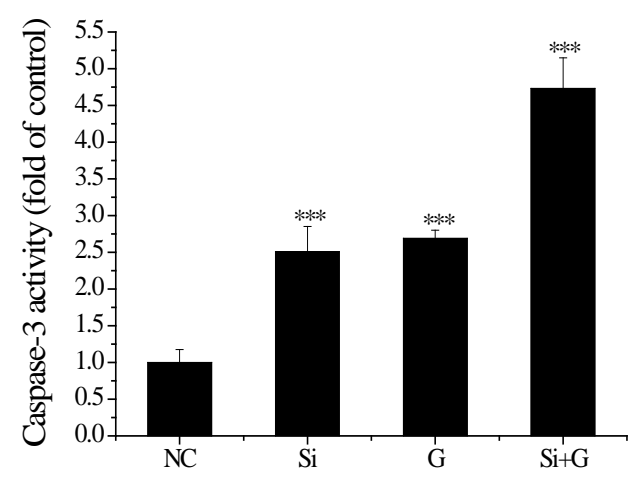

Figure 8. Effect of SelR gene knockdown on D-galactose-induced caspase-3 activity. Data are the mean $\pm \mathrm{SD}$ of at least three independent experiments. ${ }^{* * *} p<0.001$, compared to the negative control group. NC: negative control cells; Si: cells with SelR siRNA transfection for $24 \mathrm{~h}$; G: cells exposed to D-galactose (150 mM) for 36 h; Si+G: cells with SelR siRNA transfection followed by D-galactose exposure. 


\subsection{Effect of SelR Gene Knockdown on GRP78 Protein Expression in Glactose-Treated hLE Cells}

To inspect the effect of SelR gene knockdown or galactose exposure on ER stress, GRP78 protein expression was investigated by western blot in this study. As shown in Figure 8, GRP78 protein level was increased after D-galactose exposure, with value of 1.37 -fold $(p<0.001)$ of negative control cells. In SelR-gene-silenced cells followed by $150 \mathrm{mM}$ D-galactose treatment, the GRP78 protein level was 1.88 -fold $(p<0.001)$ higher compared to negative control cells (Figure 9).

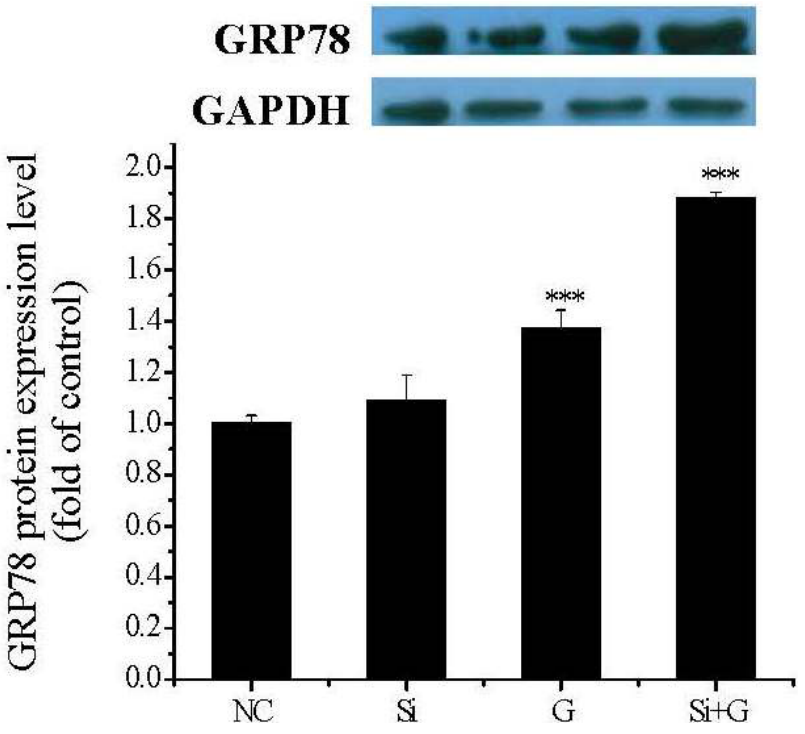

Figure 9. Effect of SelR gene knockdown on D-galactose-induced GRP78 protein expression. Data are the mean $\pm \mathrm{SD}$ of at least three independent experiments. ${ }^{* *} p<0.001$, compared to the negative control group. NC: negative control cells; Si: cells with SelR siRNA transfection for 24 h; G: cells exposed to D-galactose $(150 \mathrm{mM})$ for $36 \mathrm{~h}$; $\mathrm{Si}+\mathrm{G}$ : cells with SelR siRNA transfection followed by D-galactose exposure.

\section{Discussion}

The lens of the vertebrate eye contains a single layer of epithelial cells on its anterior surface [34], which is important for maintaining the metabolic homeostasis and transparency of the entire lens [35]. It was reported that lens epithelial cell apoptosis might be a common cellular basis for initiation of noncongenital cataract formation [30]. The incidence of apoptosis in the LE cells of diabetic cataract rats and humans was greater than that in those of non-diabetics [36]. Previous data showed that high-D-galactose concentrations significantly inhibited the percentage of hLE cells survival at 24-72 h incubation [37]. Consistently, we observed in this study that high-D-galactose concentrations could significantly increase SRA01/04 cells death and apoptosis (Figures 2 and 3). When SelR-gene-silenced SRA01/04 cells were exposed to D-galactose, the viabilities were further decreased in different concentrations of D-galactose (Figure 2). Those results suggest that SelR may decrease hLE cells apoptosis induced by D-galactose, although this role of SelR needs to be proved in vivo.

Oxidative stress has long been recognized as an important stimulus of apoptosis in lens epithelial cells and also plays a pivotal role in the pathogenesis of cataracts. Several reports showed that oxidative stress is a prime cause of diabetic complications and high D-galactose could induce excessive ROS production, promote lipid peroxidation and inhibit cell proliferation in various types of cells $[14,38-40]$ and that oxidative stress-induced ER stress could lead to apoptosis [12,41-44]. In the present study, the decrease of hLE cells viabilities was related to the significant increase of ROS, MDA and PC levels (Figure 5) induced by D-galactose; furthermore, the GRP78 protein level was significantly increased in D-galactose-stimulated hLE cells (Figure 9), indicating that ER stress occured. When the hLE 
cells treated by SelR SiRNA were exposed to D-galactose, GRP78 protein level was further increased; meanwhile, there was a similar increase for the percentage of apoptosis cells. These results imply that SelR plays important roles in protecting hLE cells against apoptosis by regulating redox balance and inhibiting ER stress resulted from D-galactose-induced oxidative stress in hLE cells.

In order to extend our knowledge of SelR protecting hLE cells by regulating redox balance, the integrity of the mitochondrial membrane potential $(\Delta \psi \mathrm{m})$ was evaluated and release of cytochrome $c$ from mitochondria was measured. It is well known that are both a source and target of ROS. Oxidation of mitochondrial pores by cytosolic ROS is one of the major reasons for the release of cytochrome $\mathrm{c}$ due to disruption of the mitochondrial membrane potential $\Delta \psi \mathrm{m}$ [45]. SelR, which contains selenocysteine and is a selenoprotein localized in the cell nucleus and cytosol, has the highest Msr activity [46] and might repair cytosolic proteins by converting oxidized Met residues (R-MetO) to Met directly [12]. In present study, our results show that when the cells were only treated with SelR knockdown by siRNA, mitochondrial dysfunction occurred; when SelR-gene-silenced cells were exposed to D-galactose $(150 \mathrm{mM})$ for $36 \mathrm{~h}$, mitochondrial dysfunction was further exacerbated, and the decrease of $\Delta \psi \mathrm{m}$ was accompanied (Figure 6) by an increased ratio of cytosolic-to-mitochondrial cytochrome c concentrations (Figure 7), meanwhile with an increased activity of caspase-3 (Figure 8), indicating a role of SelR in protection mitochondria against D-galactose-induced mitochondrial damage in hLE cells. These results further support our previous speculation [14] that oxidized methionine residues in proteins repaired by SelR may continue to react with ROS. Thus, SelR indirectly scavenges ROS in cytosol. On the other hand, the -SeH group of selenocysteine with the strong reducibility in SelR may directly react with ROS in cytosol to reduce the damage of cytosolic ROS to mitochondria. Conversely, when the SelR gene was knockdown by RNAi, SelR protein expression decreased, proteins containing R-MetO were not repaired and ROS were not scavenged, oxidative stress turns up. Oxidative stress has been demonstrated as being able to cause the burst of ROS from mitochondria which in turn induce the loss of $\Delta \psi \mathrm{m}$ [45]. When ROS accumulation reaches a critical threshold and cell's mitochondrial damage occurs, the cytochrome $\mathrm{c}$ from the mitochondria releases to cytosol, and then activates caspases apoptotic pathway [47]. As expected, our data show that treatment by only knockdown the SelR gene using siRNA or high D-galactose resulted in oxidative damage (Figure 5), an increase in cell apoptosis (Figure 3) and a decrease in cell viability (Figure 2). The present data suggest that oxidative stress plays a pivotal role in D-galactose cataract formation and SelR plays important role in protecting mitochondria against D-galactose-induced oxidative damage.

However, SelR is not only a selenoprotein in hLE cells, such as glutathione peroxidase 1 (GPx1). Flohé [5] showed that the lack of GPx-1 due to alimentary selenium deprivation was inferred to induce cataracts in rats and to cause cataracts in mice by targeted gene disruption. In the present study, our results showed that selenium supplementation could significantly decrease the percentage of apoptosis induced by D-galactose or SelR siRNA and D-galactose in hLE cells (Figure 3). When the SelR gene underwent knockdown by siRNA, selenium supplementation may have increased other selenoprotein expression; for example, GPx1 activity was elevated (Figure 4). It is clear from these results that the role of selenium protecting hLE cells against apoptosis by regulating redox balance is not only via SelR. Therefore, it is necessary to do more studies on the nutritional biochemistry of selenium in lenses.

\section{Materials and Methods}

\subsection{Materials}

Newborn calf serum (NCS), Dulbecco's Modified Eagle's Medium (DMEM), and 3-(4,5-dimethylthiazol-2-yl)-2,5-diphenylte-trazolium bromide (MTT) were purchased from Gibco BRL (Gaithersburg, MD, USA); streptomycin sulfate and Penicillin G were purchased from Amersco (Cochran, GA, USA). Lipofectamine 2000 was obtained from Invitrogen (Camarillo, CA, USA). D-Galactose and protease inhibitor cocktail were purchased from Sigma Co. (Santa Clara, CA, USA) All other chemicals were of the highest commercial grade available. 


\subsection{Cell Culture}

hLE cells were divided into six groups: negative control cells (NC), D-galactose-exposed cells (G), SelR-gene-silenced cells (Si), SelR-gene-silenced cells followed with D-galactose exposure for $36 \mathrm{~h}(\mathrm{Si}+\mathrm{G})$, cells exposed to D-galactose $(150 \mathrm{mM})$ and $\mathrm{Na}_{2} \mathrm{SeO}_{3}(1 \mu \mathrm{M})$ for $36 \mathrm{~h}(\mathrm{G}+\mathrm{Se})$ and cells with SelR siRNA transfection followed by D-galactose and $\mathrm{Na}_{2} \mathrm{SeO}_{3}$ exposure (Si+G+Se). hLE cells (SRA01/04) were maintained in DMEM supplemented with 10\% heat-inactivated newborn calf serum and antibiotics (penicillin G $100 \mathrm{U} / \mathrm{mL}$, streptomycin $100 \mu \mathrm{g} / \mathrm{mL}$ ) at $37^{\circ} \mathrm{C}$ in the presence of $5 \% \mathrm{CO}_{2}$. $\mathrm{NaHCO}_{3}$ of $0.37 \%$ was supplemented in $\mathrm{NC}$ and $\mathrm{Si}$ groups, $0.1 \%$ in other groups.

In order to detect influence of different osmolarity to cell, we added $75 \mathrm{mM} \mathrm{NaCl}$ in medium to match the increased osmolarity of the $150 \mathrm{mM}$ galactose for the $36 \mathrm{~h}$ and then evaluated the effect of supplemented $\mathrm{NaCl}$ on cell viability (Figure S1A) and cell apoptosis (Figure S1B). The results showed that there were not significant changes on cell viability and cell apoptosis in $\mathrm{NaCl}$ group compared to normal control group.

\subsection{SelR RNA Interference and Cell Treatment}

Double-stranded short interfering RNAs (siRNA) specific for SelR were 5'-GCGUCCGGAGCA CAAUAGATT-3' (sense) and 5'-UCUAUUGUGCUCCGGACGCTT-3' (antisense) [13], and 5'-UUC UCCGAACGUGUCACGUTT-3' (sense) and 5'-ACGUGACACGUUCGGAGAATT-3' (antisense) for negative control. siRNAs were synthesized by Shanghai GenePharma (Shanghai, China).

Cells of the $\mathrm{Si}, \mathrm{Si}+\mathrm{G}$ and $\mathrm{Si}+\mathrm{G}+\mathrm{Se}$ groups were transfected with siRNA as described in previous works [48]. After $24 \mathrm{~h}$, all groups were treated with fresh serum-free media with or without D-galactose $(150 \mathrm{mM})$ and $\mathrm{Na}_{2} \mathrm{SeO}_{3}$ for $36 \mathrm{~h}$. hLE cells were then harvested for further analysis.

\subsection{Cell Viability Assay}

Cell viability was measured by MTT assay [49]. The absorbance was measured at $570 \mathrm{~nm}$ using a spectrophotometer (Cecil, Nottingham Model No. CE7200; Cambridge, UK) and expressed as percent of the absorbance in untreated control cells in parallel wells [46].

\subsection{Isolation of Total RNA and Real-Time PCR}

According to the manufacturer's instruction, total RNAs were extracted from the hLE cells using Trizol reagent (Invitrogen). cDNA was obtained by incubation of the mRNA with M-MLV reverse transcriptase (Toyobo, Osaka, Japan), oligo (dT) (Toyobo) and dNTPs (Toyobo) at $42{ }^{\circ} \mathrm{C}$ for $40 \mathrm{~min}$ in the buffer (Toyobo). After inactivation of the enzyme by incubation at $95{ }^{\circ} \mathrm{C}$ for $5 \mathrm{~min}$, polymerase chain reaction (PCR) was carried. The primer sequences are as follow: SelR: 5'-ATGTCGTTCTGCAGCTTCTTC-3' (forward) and 5'-CACACTTGCCACAGGACAC-3' (reverse) [50]; GAPDH: 5'-CCATGTTCGTCATGGGTGTGAACCA-3' (forward) and 5'-GCCAGTAGAGGCAGGG ATGATGTTC-3' (reverse) [51]; Real-time PCR was performed in DNA Engine Opticon 2 (MJ Research, Watertown, MA, USA). PCR conditions for SelR were $95^{\circ} \mathrm{C}$ for $10 \mathrm{~min}$ followed by 40 cycles of $95^{\circ} \mathrm{C}$ for $15 \mathrm{~s}$ and $60^{\circ} \mathrm{C}$ for $1 \mathrm{~min}$; for GAPDH, the conditions were referred [51].

\subsection{Western Blot Analysis}

Western blots were processed as described in previous work [51,52]. Briefly, hLE cells $\left(\sim 1 \times 10^{7}\right.$ cells per sample) were lysed on ice for $20 \mathrm{~min}$ in westen lysis buffer and protein extracts were obtained by centrifugation $\left(4^{\circ} \mathrm{C}, 12,000 \times g\right.$ for $\left.15 \mathrm{~min}\right)$. Protein concentration was analyzed using the Bradford assay. After SDS-PAGE and transferred electrophoretically to polyvinylidene fluoride (PVDF) membranes, the membranes were blocked for $120 \mathrm{~min}$ at room temperature with 5\% (w/v) non-fat milk. Then the blots was incubated overnight at $4{ }^{\circ} \mathrm{C}$ with $5 \%$ non-fat milk in TBS-T containing antibodies for SelR (Abcam, Cambridge, UK), GAPDH (Beyotime Inst. Biotech, Haimen, China), GRP78 (Beyotime Inst. Biotech). After four washes with TBS-T, the blot was incubated for 90 min at 
room temperature with secondary antibodies diluted at 1:3000 in 5\% non-fat milk in TBS-T. Protein bands were identified using an enhanced chemiluminescence (ECL) system (Millipore, Boston, MA, USA). Quantification of protein band in X-ray film was scanned and analyzed with Bio-Rad Quantity One software (Hercules, CA, USA). Protein levels for SelR and GRP78 were normalized to GAPDH.

\subsection{Measurement of GPx Activity}

GPx activity was measured using GPx kit (Jiancheng, Nanjing, China) according to the manufacturer's protocol.

\subsection{Measurement of ROS, MDA, PC and TSH}

ROS level was assayed using a fluorescence microscope with the fluorescent probe $2^{\prime}, 7^{\prime}$-dichlorodihydro-fluorescein diacetate (DCFH-DA; Beyotime, Haimen, China). For the quantitative analysis of intracellular ROS, cells were collected by trypsinization as described above, incubated with DCFH-DA, and washed three times, then resuspended in serum-free DMEM and DCF fluorescence (excitation, $485 \mathrm{~nm}$ and emission, $525 \mathrm{~nm}$ ) was measured by flow cytometry (FC500, BeckMan Coulter, Brea, CA, USA). The data are presented as the mean fluorescence intensity, and are normalized to the normal control value.

MDA and TSH were detected using measurement kits (Jiancheng, Nanjing, China). The absorbance was measured at $532 \mathrm{~nm}$ for MDA and $412 \mathrm{~nm}$ for TSH according to the manufacturer's protocol, respectively.

The protein carbonyl (PC) content was determined by a DNPH assay [53].

\subsection{Detection of Apoptosis}

Cell apoptosis was quantified by flow cytometry (FC500, Beckman Coulter) using an Annexin-V-FITC apoptosis detection kit (Beyotime Inst. Biotech) according to the manufacturer's protocol [11]. Percentage of early apoptotic and late apoptotic cells was shown in C2 and C4 areas, respectively.

Then nuclear morphology was observed using a fluorescence microscope (IX71, Olympus; Tokyo, Japan). The hLE cells plated in 6-well plates were harvested and washed with PBS, then fixed with methanol and acetic acid $(3: 1, v / v)$ for $20 \mathrm{~min}$ at room temperature. After washing, cells were stained with Hoechst 33258 (Sigma) for $30 \mathrm{~min}$ at room temperature.

\subsection{Assay of Cell Caspase-3 Activity}

The activity of caspase- 3 was assayed using the caspase- 3 activity assay kit (Beyotime Inst. Biotech) according to the manufacturer's protocol. The samples were measured with a microplate reader (Molecular Devices Spectramax 384, San Francisco, CA, USA) at $405 \mathrm{~nm}$ and the data were normalized to the control value $[54,55]$.

\subsection{Detection of Mitochondrial Membrane Potential $(\Delta \psi m)$}

The integrity of the mitochondrial membrane potential $(\Delta \psi \mathrm{m})$ was evaluated using a cationic dye, JC-1 (5,5',6,6' -tetrachloro-1,1',3,3'-tetrabenzimidazole-carbocyanine iodide) (Beyotime Inst. Biotech). Briefly, cells were collected by trypsinization as described above. Then cells were incubated in JC-1 $\left(5 \mu \mathrm{g} / \mathrm{mL}\right.$, dissolved in serum-free medium) for $30 \mathrm{~min}$ at $37^{\circ} \mathrm{C}$. After washing with PBS, the mean green fluorescence (FL-1 channel) and mean orange-red fluorescence (FL-2 channel) were quantified using flow cytometry (BD ${ }^{\mathrm{TM}}$ LSR II, San Jose, CA, USA). $\Delta \psi \mathrm{m}$ was expressed as the ratio of mean red to mean green fluorescence and [56] normalized using normal control value. 


\subsection{Release of Cytochrome c from Mitochondria}

The cytochrome c release from the mitochondria was detected uing a human cytochrome $\mathrm{c}$ ELISA Kit (R \& D Systems, Inc., Minneapolis, MN, USA). The mitochondrial and cytosolic fractions of hLE cells $\left(\sim 1 \times 10^{7}\right.$ cells per sample) were separated using a mitochondria/cytosol fractionation kit (Beyotime Inst. Biotech). The purity of mitochondrial and cytosolic fractions was detected by measuring coxiv and actin protein expressions using Western blot $[57,58]$. The concentration of protein was determined using the Bradford assay. The cytochrome c concentration ( $\mathrm{ng} / \mathrm{mg}$ of total protein) was determined using the ELISA kit. The data were expressed as the ratio of cytosolic-to-mitochondrial cytochrome c concentrations $[59,60]$.

\subsection{Statistical Analysis}

Representative results from at least three independent experiments are shown as the mean \pm the standard deviation. Data analysis was performed by one-way analysis of variance. For comparison of two groups, Student's $t$ test was used. $p<0.05$ was considered statistically significant.

\section{Conclusions}

In summary, both D-galactose and SelR gene knockdown by siRNA independently aggravate the oxidative damage in hLE cells; furthermore, the SelR gene knockdown followed by D-galactose treatment could significantly result in ER stress and increase apoptosis accompanying by a decrease of $\Delta \psi \mathrm{m}$ and a release of mitochondrial cytochrome $\mathrm{c}$, indicating that mitochondrial dysfunction occurred in hLE cells. The results suggest that SelR may play important roles in protecting hLE cell mitochondria against oxidative damage and inhibiting the D-galactose-induced oxidative stress-induced apoptosis in hLE cells by scavenging ROS. However, the role of selenium protecting hLE cells against apoptosis by regulating redox balance is not only via SelR. So it is necessary to do more studies on the nutritional biochemistry of selenium in lens.

Supplementary Materials: Supplementary materials can be found at http://www.mdpi.com/1422-0067/ 17/2/231/s1.

Acknowledgments: This work was supported by grants from the National Natural Science Foundation of China (Project No. 21271077). We give our sincerely thanks to the faculties from Analytical and Testing Centre of Huazhong University of Science and Technology for their help in the Bioanalysis.

Author Contributions: Conceived and designed the study, interpreted data and wrote the manuscript: Kaixun Huang and Jie Dai; performed the experiments and analyzed the data: Jie Dai; study design and discussion: Hongmei Liu and Jun Zhou.

Conflicts of Interest: The authors declare no conflict of interest.

\section{Abbreviations}

$\begin{array}{ll}\text { cDNA } & \text { Complementary DNA } \\ \text { DCFH-DA } & 2^{\prime}, 7^{\prime} \text {-Dichlorodihydro-fluorescein diacetate } \\ \text { DMEM } & \text { Dulbecco's modified Eagle's medium } \\ \text { ECL } & \text { Enhanced chemiluminescence } \\ \text { ER } & \text { Endoplasmic reticulum } \\ \text { FITC } & \text { Fluorescein isothiocyanate } \\ \text { GPx } & \text { Glutathione peroxidase } \\ \text { GRP78 } & \text { Glucose-regulated protein } \\ \text { hLE cells } & \text { Human lens epithelial cells } \\ \text { JC-1 } & 5,5^{\prime}, 6,6^{\prime} \text {-Tetrachloro-1,1',3,3'-tetraethyl-imidacarbocyanine iodide } \\ \text { MDA } & \text { Malondialdehyde } \\ \text { MetO } & \text { Methionine sulfoxide } \\ \text { Msr } & \text { Methionine sulfoxide reductase } \\ \text { MTT } & \text { 3-(4,5-Dimethylthiazol-2-yl)-2,5-diphenylte-trazolium bromide }\end{array}$




$\begin{array}{ll}\text { NCS } & \text { Newborn calf serum } \\ \text { PBS } & \text { Phosphate-buffered saline } \\ \text { PC } & \text { Protein carbonyl } \\ \text { PI } & \text { Propidium iodide } \\ \text { ROS } & \text { Reactive oxygen species } \\ \text { SelR } & \text { Selenoprotein R } \\ \text { siRNA } & \text { Short interfering RNA } \\ \text { TBS-T } & \text { Tris-buffered saline with Tween } \\ \text { TSH } & \text { Total mercapto group } \\ \Delta \psi \mathrm{m} & \text { Mitochondrial membrane potential }\end{array}$

\section{References}

1. Kryukov, G.V.; Castellano, S.; Novoselov, S.V.; Lobanov, A.V.; Zehtab, O.; Guigó, R.; Gladyshev, V.N. Characterization of mammalian selenoproteomes. Science 2003, 300, 1439-1443. [CrossRef] [PubMed]

2. Kryukov, G.V.; Gladyshev, V.N. The prokaryotic selenoproteome. EMBO Rep. 2004, 5, 538-543. [CrossRef] [PubMed]

3. Castellano, O.; Bermúdez, Y.; Giffard, M.; Mabon, G.; Cubillan, N.; Sylla, M.; Nguyen-Phu, X.; Hinchliffe, A.; Soscún, $\mathrm{H}$. Ab initio and DFT study of the geometric structures and static dipole (hyper) polarizabilities of aromatic anions. J. Phys. Chem. A 2005, 109, 10380-10387. [CrossRef] [PubMed]

4. Zhang, J.; Wang, H.; Yan, X.; Zhang, L. Comparison of short-term toxicity between Nano-Se and selenite in mice. Life Sci. 2005, 76, 1099-1109. [CrossRef] [PubMed]

5. Flohé, L. Selenium, selenoproteins and vision. Dev. Ophthalmol. 2005, 38, 89-102. [PubMed]

6. Zhu, X.; Lu, Y. Selenium supplementation can slow the development of naphthalene cataract. Curr. Eye Res. 2012, 37, 163-169. [CrossRef] [PubMed]

7. Garner, M.H.; Spector, A. Selective oxidation of cysteine and methionine in normal and senile cataractous lenses. Proc. Natl. Acad. Sci. USA 1980, 77, 1274-1277. [CrossRef] [PubMed]

8. Kantorow, M.; Hawse, J.R.; Cowell, T.L.; Benhamed, S.; Pizarro, G.O.; Reddy, V.N.; Hejtmancik, J.F. Methionine sulfoxide reductase $\mathrm{A}$ is important for lens cell viability and resistance to oxidative stress. Proc. Natl. Acad. Sci. USA 2004, 101, 9654-9659. [CrossRef] [PubMed]

9. Davies, M.J. The oxidative environment and protein damage. Biochim. Biophys. Acta 2005, 1703, 93-109. [CrossRef] [PubMed]

10. Reeves, M.A.; Hoffmann, P.R. The human selenoproteome: Recent insights into functions and regulation. Cell Mol. Life Sci. 2009, 66, 2457-2478. [CrossRef] [PubMed]

11. Levine, R.L.; Mosoni, L.; Berlett, B.S.; Stadtman, E.R. Methionine residues as endogenous antioxidants in proteins. Proc. Natl. Acad. Sci. USA 1996, 93, 15036-15040. [CrossRef] [PubMed]

12. Kim, H.Y.; Gladyshev, V.N. Methionine sulfoxide reductases: Selenoprotein forms and roles in antioxidant protein repair in mammals. Biochem. J. 2007, 407, 321-329. [CrossRef] [PubMed]

13. Marchetti, M.A.; Pizarro, G.O.; Sagher, D.; DeAmicis, C.; Brot, N.; Hejtmancik, J.F.; Weissbach, H.; Kantorow, M. Methionine sulfoxide reductases B1, B2, and B3 are present in the human lens and confer oxidative stress resistance to lens cells. Investig. Ophthalmol. Vis. Sci. 2005, 46, 2107-2112. [CrossRef] [PubMed]

14. Li, Y.; Jia, Y.; Zhou, J.; Huang, K.X. Effect of methionine sulfoxide reductase B1 silencing on high-glucose-induced apoptosis of human lens epithelial cells. Life Sci. 2013, 92, 193-201. [CrossRef] [PubMed]

15. Jia, Y.; Li, Y.; Du, S.Q.; Huang, K.X. Involvement of MsrB1 in the regulation of redox balance and inhibition of peroxynitrite-induced apoptosis in human lens epithelial cells. Exp. Eye Res. 2012, 100, 7-16. [CrossRef] [PubMed]

16. Jia, Y.; Zhou, J.; Du, S.Q.; Liu, H.M.; Huang, K.X. Effect of methionine sulfoxide reductase B1 (SelR) gene silencing on peroxynitrite-induced F-actin disruption in human lens epithelial cells. Biochem. Biophys. Res. Commun. 2014, 443, 876-881. [CrossRef] [PubMed] 
17. Acosta, P.B.; Gross, K.C. Hidden sources of galactose in the environment. Eur. J. Pediatr. 1995, 154, 87-92. [CrossRef]

18. Wu, D.M.; Lu, J.; Zheng, Y.L.; Zhou, Z.; Shan, Q.; Ma, D.F. Purple sweet potato color repairs D-galactose-induced spatial learning and memory impairment by regulating the expression of synaptic proteins. Neurobiol. Learn. Mem. 2008, 90, 19-27. [CrossRef] [PubMed]

19. Agarwal, R.; Lezhitsa, I. Effects of magnesium taurate on the onset and progression of D-galactose-induced experimental cataract: In vivo and in vitro evaluation. Exp. Eye Res. 2013, 110, 35-43. [CrossRef] [PubMed]

20. Datiles, M.B.; Kador, P.F.; Fukui, H.N.; Hu, T.S.; Kinoshita, J.H. Corneal re-epithelialization in D-galactosemic rats. Investig. Ophthalmol. Vis. Sci. 1983, 24, 563-569.

21. Hu, T.S.; Datiles, M.; Kinoshita, J.H. Reversal of D-galactose cataract with Sorbinil in rats. Investig. Ophthalmol. Vis. Sci. 1983, 24, 640-644.

22. Sakthivel, M.; Geraldine, P.; Thomas, P.A. Alterations in the lenticular protein profile in experimental selenite-induced cataractogenesis and prevention by ellagic acid. Graef Arch. Clin. Exp. 2011, 249, 1201-1210. [CrossRef] [PubMed]

23. Li, W.C.; Kuszak, J.R.; Dunn, K.; Wang, R.R.; Ma, W.; Wang, G.M.; Spector, A.; Leib, M.; Cotliar, A.M.; Weiss, M. Lens epithelial cell apoptosis appears to be a common cellular basis for noncongenital cataract development in humans and animals. J. Cell Biol. 1995, 130, 169-181. [CrossRef] [PubMed]

24. Devi, V.G.; Rooban, B.N.; Sasikala, V.; Sahasranamam, V.; Abraham, A. Isorhamnetin-3-glucoside alleviates oxidative stress and opacification in selenite cataract in vitro. Toxicol. In Vitro 2010, 24, 1662-1669. [CrossRef] [PubMed]

25. Ohta, Y.; Torii, H.; Yamasaki, T.; Niwa, T.; Majima, Y.; Ishiguro, I. Preventive action of vitamin E-containing liposomes on cataractogenesis in young adult rats fed a 25\% D-galactose diet. J. Ocul. Pharmacol. Ther. 1997, 13, 537-550. [CrossRef] [PubMed]

26. Ohta, Y.; Yamasaki, T.; Niwa, T.; Goto, H.; Majima, Y.; Ishiguro, I. Cataract development in 12-Month-Old Rats Fed a 25\% D-Galactose Diet and Its Relation to Osmotic Stress and Oxidative Damage. Ophthalmic Res. 1999, 31, 321-331. [CrossRef] [PubMed]

27. Gupta, P.P.; Pandey, D.J.; Sharma, A.L.; Strivastava, R.K.; Mishra, S.S. Prevention of experimental cataract by $\alpha$-tocopherol. Indian J. Exp. Biol. 1984, 22, 620-622. [PubMed]

28. Hirai, T.; Majima, Y.; Ohta, Y.; Ishiguro, I. Relationship between lenticular vitamin E level and cataract formation in D-galactosemic rats. Folia Ophthalmol. Jpn. 1986, 37, 1266-1270.

29. Srivastava, S.K.; Ansari, N.H. Prevention of sugar-induced cataractogenesis in rats by butylated hydroxytoluene. Diabetes 1988, 37, 1505-1508. [CrossRef] [PubMed]

30. Takamura, Y.; Sugimoto, Y.; Kubo, E.; Takahashi, Y.; Akagi, Y. Immunohistochemical study of apoptosis of lens epithelial cells inhumanand diabetic rat cataracts. Jpn. J. Ophthalmol. 2001, 45, 559-563. [CrossRef]

31. Mulhern, M.L.; Madson, C.J.; Danford, A.; Ikesugi, K.; Kador, P.F.; Shinohara, T. The unfolded protein response in lens epithelial cells from D-galactosemic rat lenses. Investig. Ophthalmol. Vis. Sci. 2006, 47, 3951-3959. [CrossRef] [PubMed]

32. Mia, A.; Zhang, X.; Jiang, Y.; Chen, Y.; Fang, Y.; Ye, H.; Chu, R.; Lu, Y. Proteomic analysis of SRA01/04 transfected with wild-type and mutant HSF4b identified from a Chinese congenital cataract family. Mol. Vis. 2012, 18, 694-704.

33. Ceriello, A.; Bortolotti, N.; Crescentini, A.; Motz, E.; Lizzio, S.; Russo, A.; Ezsol, Z.; Tonutti, L.; Taboga, C. Antioxidant defences are reduced during the oral glucose tolerance test in normal and non-insulin-dependent diabetic subjects. Eur. J. Clin. Investig. 1998, 28, 329-333. [CrossRef]

34. Bloemendal, H.; Benedetti, E.L.; Ramaekers, F.; Dunia, I. The lens cytoskeleton. Intermediate-sized filaments, their biosynthesis and association with plasma membranes. Mol. Biol. Rep. 1981, 7, 167-168. [CrossRef] [PubMed]

35. Spector, A. On presentation of the proctor medal of the association for research in vision and ophthalmology to Dr. Hans Bloemendal. Investig. Ophthalmol. Vis. Sci. 1991, 32, 443-444.

36. Wang, X.; Wang, Z.; Liu, J.Z.; Hu, J.X.; Chen, H.L.; Li, W.L.; Hai, C.X. Double antioxidant activities of rosiglitazone against high glucose-induced oxidative stress in hepatocyte. Toxicol. In Vitro 2011, 25, 839-847. [CrossRef] [PubMed]

37. Ou, Y.; Liao, G.Y.; Wu, W.T. Potential use of hirudin in diabetic cataract: A study of D-galactose mediated human lens epithelial cells injury. Chem. Biol. Interact. 2008, 173, 141-147. [CrossRef] [PubMed] 
38. Hunt, J.V.; Wolff, S.P. Oxidative glycation and free radical production: A causal mechanism of diabetic complications. Free Radic. Res. Commun. 1991, 12, 115-123. [CrossRef] [PubMed]

39. Lee, A.Y.W.; Chung, S.S.M. Contributions of polyol pathway to oxidative stress in diabetic cataract. FEBS Lett. 1999, 13, 23-30.

40. Kubo, E.; Miyoshi, N.; Fukuda, M.; Akagi, Y. Cataract formation through polyol pathway is associated with free radical production. Exp. Eye Res. 1999, 68, 457-464. [CrossRef] [PubMed]

41. Yokouchi, M.; Hiramatsu, N.; Hayakawa, K.; Okamura, M.; Du, S.; Kasai, A.; Takano, Y.; Shitamura, A.; Shimada, T.; Yao, J.; et al. Involvement of selective reactive oxygen species upstream of proapoptotic branches of unfolded protein response. J. Biol. Chem. 2008, 283, 4252-4260. [CrossRef] [PubMed]

42. Tagawa, Y.; Hiramatsu, N.; Kasai, A.; Hayakawa, K.; Okamura, M.; Yao, J.; Kitamura, M. Induction of apoptosis by cigarette smoke via ROS-dependent endoplasmic reticulum stress and CCAAT/enhancer-binding protein-homologous protein (CHOP). Free Radic. Biol. Med. 2008, 45, 50-59. [CrossRef] [PubMed]

43. Pan, C.; Giraldo, G.S.; Prentice, H.; Wu, J.Y. Taurine protection of PC12 cells against endoplasmic reticulum stress induced by oxidative stress. J. Biomed. Sci. 2012, 17. [CrossRef] [PubMed]

44. Dejeans, N.; Tajeddine, N.; Beck, R.; Verrax, J.; Taper, H.; Gailly, P.; Calderon, P.B. Endoplasmic reticulum calcium release potentiates the ER stress and cell death caused by an oxidative stress in MCF-7 cells. Biochem. Pharmacol. 2010, 79, 1221-1230. [CrossRef] [PubMed]

45. Balakrishnan, K.; Wierda, W.G.; Keating, M.J.; Gandhi, V. Gossypol, a BH3 mimetic, induces apoptosis in chronic lymphocytic leukemia cells. Blood 2008, 112, 1971-1980. [CrossRef] [PubMed]

46. Xu, A.; Prophete, C.; Chen, L.C.; Emala, C.W.; Cohen, M.D. Interactive effect of cigarette smoke extract and world trade center dust particles on airway cell cytotoxicity. J. Toxicol. Environ. Health 2011, 74, 887-902. [CrossRef] [PubMed]

47. Brennan, L.A.; Lee, W.; Cowell, T.; Giblin, F.; Kantorow, M. Deletion of mouse MsrA results in HBO-induced cataract: MsrA repairs mitochondrial cytochrome c. Mol. Vis. 2009, 15, 985-999. [PubMed]

48. Zeng, J.H.; Du, S.Q.; Zhou, J.; Huang, K.X. Role of SelS in lipopolysaccharide-induced inflammatory response in hepatoma HepG2 cells. Arch. Biochem. Biophys. 2008, 478, 1-6. [CrossRef] [PubMed]

49. Ohguro, N.; Fukuda, M.; Sasabe, T.; Tano, Y. Concentration dependent effects of hydrogen peroxide on lens epithelial cells. Br. J. Ophthalmol. 1999, 83, 1064-1068. [CrossRef] [PubMed]

50. Luca, A.D.; Sacchetta, P.; Nieddu, M.; Ilio, C.D.; Favaloro, B. Important roles of multiple Sp1 binding sites and epigenetic modifications in the regulation of the methionine sulfoxide reductase B1 (MsrB1) promoter. BMC Mol. Biol. 2007, 8, 39-50. [CrossRef] [PubMed]

51. Du, S.Q.; Zhou, J.; Jia, Y.; Huang, K.X. SelK is a novel ER stress-regulated protein and protects HepG2 cells from ER stress agent-induced apoptosis. Arch Biochem. Biophys. 2010, 502, 137-143. [CrossRef] [PubMed]

52. Li, Y.; Zhang, W.; Li, P.; Huang, K. Effect of streptozocin-induced diabetes mellitus on expression of methionine sulfoxide reductases and accumulation of their substrates in mouse lenses. Exp. Eye Res. 2011, 92, 401-407. [CrossRef] [PubMed]

53. Cao, G.; Cutler, R.G. Protein oxidation and aging. I. difficulties in measuring reactive protein carbonyls in tissues using 2,4-dinitrophenylhydrazine. Arch Biochem. Biophys. 1995, 320, 106-114. [CrossRef] [PubMed]

54. Bejma, J.; Ji, L.L. Aging and acute exercise enhance free radical generation in rat skeletal muscle. J. Appl. Physiol. 1999, 87, 465-470. [PubMed]

55. Agrawal, S.S.; Saraswati, S.; Mathur, R.; Pandey, M. Cytotoxic and antitumor effects of brucine on Ehrlich ascites tumor and human cancer cell line. Life Sci. 2011, 89, 147-158. [CrossRef] [PubMed]

56. McElnea, E.M.; Quill, B.; Docherty, N.G.; Irnaten, M.; Siah, W.F.; Clark, A.F.; O’Brien, C.J.; Wallace, D.M. Oxidative stress, mitochondrial dysfunction and calcium overload in human lamina cribrosa cells from glaucoma donors. Mol. Vis. 2011, 17, 1182-1191. [PubMed]

57. Kowluru, R.A.; Abbas, S.N. Diabetes-induced mitochondrial dysfunction in the retina. Investig. Ophthalmol. Vis. Sci. 2003, 44, 5327-5334. [CrossRef]

58. Yamada, T.; Goto, M.; Punj, V.; Zaborina, O.; Chen, M.L.; Kimbara, K.; Majumdar, D.; Cunningham, E.; Das Gupta, T.K.; Chakrabarty, A.M. Bacterial redox protein azurin, tumor suppressor protein p53, and regression of cancer. Proc. Natl. Acad. Sci. USA 2002, 99, 14098-14103. [CrossRef] [PubMed] 
59. Ventéo, L.; Bourlet, T.; Renois, F.; Douche-Aourik, F.; Mosnier, J.F.; Maison, G.L.; Pluot, M.; Pozzetto, B.; Andreoletti, L. Enterovirus-related activation of the cardiomyocyte mitochondrial apoptotic pathway in patients with acute myocarditis. Eur. Heart J. 2010, 31, 728-36. [CrossRef] [PubMed]

60. Sommer, S.P.; Sommer, S.; Sinha, B.; Walter, D.; Aleksic, I.; Gohrbandt, B.; Otto, C.; Leyh, R.G. Glutathione preconditioning ameliorates mitochondria dysfunction during warm pulmonary ischemia-reperfusion injury. Eur. J. Cardiothorac. Surg. 2011, 41, 140-148. [CrossRef] [PubMed]

(C) 2016 by the authors; licensee MDPI, Basel, Switzerland. This article is an open access article distributed under the terms and conditions of the Creative Commons by Attribution (CC-BY) license (http://creativecommons.org/licenses/by/4.0/). 